\title{
FATTY ACID COMPOSITION OF Longissimus dorsi MUSCLE OF SUFFOLK DOWN LAMBS FED ON DIFFERENT DRYLAND FORAGES
}

\author{
María Asunción Gallardo ${ }^{1 *}$, Rubén Pulido ${ }^{1}$, and Carmen Gallo ${ }^{1}$
}

\begin{abstract}
Sheep production on dryland is based on natural pasture. The aim of this study was to evaluate the effect of dryland legume pastures on the fatty acid composition of lamb meat. The study included 21 Suffolk Down male lambs aged about 2-mo that were randomly assigned to three types of pastures: successional pasture, subterranean clover/Wimmera ryegrass (Trifolium subterraneum L./Lolium rigidum Gaudin), or red clover/Wimmera ryegrass (T. pratense L./L. rigidum) for $66 \mathrm{~d}$, and slaughtered after. The fatty acid profile measured in the Longissimus dorsi muscle showed no significant differences as to the content of saturated (SFA), polyunsaturated fatty acids (PUFA), and the omega6/omega3 rate ( $\omega 6 / \omega 3)$. There was a trend $(\mathrm{p}>0.06)$ towards a higher monounsaturated fatty acid (MUFA) content in the meat of lambs fed on red clover when compared to the other pasture types. Although there were no significant differences among treatments, the results obtained with natural pasture cannot be extrapolated to natural dryland pastures due to their high legume content. It is concluded that using subterranean clover/Wimmera ryegrass would provide a similar meat quality when compared to results obtained from forage based on red clover/Wimmera ryegrass.
\end{abstract}

Key words: Lamb meat, muscle fat, legume pastures.

$\mathrm{T}$ he Maule Region in Chile is characterized by its agricultural and animal production. It has a vast extension of dryland pastures which, under the framework of sustainable production, offer an interesting forage potential for sheep production. Experimental research shows that new forage species introduced into the country are able to improve pasture production in the region by increasing herbage mass (Avendaño et al., 2005and animal weight gains (Gallardo et al., 2008).

Enhancing the content of polyunsaturated fatty acids (PUFA) omega 3 in animal products is a good strategy to increase the contribution of these fatty acids in the human diet (Andersson et al., 2002). Special attention must be given to its precursor, $\alpha$-linolenic acid (ALNA) that is present in forages. Although ALNA constitutes a highly limited source of fatty acids for humans, it is a good productive alternative due to its low susceptibility to biohydrogenation and lower costs when compared with PUFA present in fish oil (Givens et al., 2006).

In contrast to pork, ruminant meat is characterized by a lower proportion of essential fatty acids, such as linoleic acid (18:2 n-6) and ALNA (18:3 n-3), which can be due to the reducing role produced by ruminal bacteria on double bonds, thus saturating dietary fatty acids (Wood et al., 2008).

${ }^{1}$ Universidad Austral de Chile, Facultad de Ciencias Veterinarias, PO Box 567, Valdivia, Chile. *Corresponding author (mugallar@gmail. com).

Received: 17 March 2011.

Accepted: 8 August 2011.
In non-ruminants, the diet profile of fatty acids is almost closely reflected in body fat, both on superficial and infiltrated fat (Gallardo, 2004). Nevertheless, that effectiveness in ruminants is reduced by ruminal hydrogenation. Certain forages with high PUFA omega 3 contents (such as red clover (Trifolium pratense L.) have been proven as able to protect themselves from this ruminal biohydrogenation (Lee et al., 2009a). This can be reflected in the fat of ruminants, and in their meat for human consumption, thus benefiting health by reducing the risk of chronic diseases, such as coronary diseases, cancer, obesity, and type 2 diabetes (Simopoulos, 2000).

Although the introduction of subterranean clover (Trifolium subterraneum L.) in Chile's dryland area has been under study for $5 \mathrm{yr}$, there is no information about its effects on meat composition. The hypothesis formulated that the use of dryland legume pastures would improve lamb meat fatty acid composition. The aim of this study was to evaluate the effect of grazing dryland legume pastures on lamb meat fatty acid composition in the Maule Region.

\section{MATERIALS AND METHODS}

The trial was carried out on the inner dryland of the Maule Region. Twenty-one Suffolk Down entire male lambs were used without differentiating the ewe parturition number (third parturition), lamb age (approximately 2 $\mathrm{mo}$ ), and live weight (average weight $29.5 \pm 3.35 \mathrm{~kg}$ ). Lambs were identified by ear tags and randomly assigned 
along with their mothers (without weaning) to three treatments each with seven animals for a period of $66 \mathrm{~d}$. Treatments consisted of continuous ad-libitum grazing (pasture height was never lower than $7 \mathrm{~cm}$ ), successional pasture, post cultivation (a naturalized pasture planted with legumes in previous years that germinates when temperature and humidity conditions are suitable and occurs spontaneously), pasture mainly with subterranean clover/Wimmera ryegrass (Trifolium subterraneum L./ Lolium rigidum Gaudin), and pasture mainly with red clover/Wimmera ryegrass (T. pratense L./L. rigidum). Each pasture consisted of 5 ha; lambs had permanent water availability. Before starting the trial, all lambs were grazing on successional pasture. Once assigned to the treatments, one group continued grazing the same pasture, another group started to graze on the subterranean clover/ Wimmera ryegrass pasture, and another started to graze on the red clover/Wimmera ryegrass pasture.

The day the trial started (10 October 2009), forage samples from each pasture were taken with exclusion cages where five random samples per pasture were collected and the harvested material of each pasture was pooled in order to obtain one composite and representative sample for each treatment. This procedure was repeated on 11 November and 15 December 2009. Samples were sent to the Forage Laboratory of the Animal Production Department of the Universidad Austral de Chile, Valdivia to be analyzed. The botanic composition of each pasture for each sampling was obtained by manually separating the species and then dried in an oven at $60{ }^{\circ} \mathrm{C}$ for $48 \mathrm{~h}$.

Before beginning the trial, samples of Longissimus dorsi muscle were obtained from four lambs, randomly chosen from each treatment, through a biopsy procedure carried out on the right side of the loin between the 10th and 13th ribs. A trichotomy was performed in the described area before the biopsy. The biopsy procedure included a local anesthetic ( $4 \mathrm{~mL}$ lidocaine $2 \%$ by infiltration) and surgical instruments. After the anesthetic infiltration, the skin was dissected to reach the L. dorsi muscle. A muscle sample (triangular shape) of approximately $3 \mathrm{~g}$ was obtained from each lamb. Finally, the muscle and the skin were sutured, and an anti inflammatory $(1.5 \mathrm{~mL}$ flunixin meglumine) and antibiotic (3 $\mathrm{mL}$ oxytetracycline $5 \%$ ) were applied intramuscularly. Therefore, samples of the four lambs had to be grouped into only one initial sample per treatment (three initial samples), which were kept in Eppendorf tubes at $-20{ }^{\circ} \mathrm{C}$ for analyses.

Two days after the trial ended, lambs were slaughtered according to the standards of Chile's meat industry. Samples of approximately $80-\mathrm{g}$ of $L$. dorsi muscle were taken from all lambs immediately after death and homogenized by interrupted grinding in a Moulinex device for $30 \mathrm{~s}$ and kept in hermetic bags at a temperature of $-20{ }^{\circ} \mathrm{C}$ for further analyses.

The following productive variables were measured and then calculated: initial live weight, final live weight, weight immediately before slaughter (after transport and fasting), hot carcass weight, daily weight gain (DWG), and carcass dressing percentage (using weight before slaughter).

Chemical analyses were carried out for both the forage and muscle samples to determine dry matter content (DM), total ashes (TA), and crude protein (CP) (Bateman, 1970). Metabolizable energy (ME) was estimated by regression with a "D" value (Digestible organic matter/DM × 100) determinated in vitro (Tilley and Terry, 1963) according to Goering and Van Soest (1970). This trial also determined neutral detergent fiber (NDF) (Van Soest et al., 1991), acid detergent fiber (ADF), and crude fiber (AOAC, 1996). Muscle samples were grouped according to the treatment received, they were thawed and lyophilized before being chemically analyzed.

Fatty acid composition in both forage and muscle was measured at the Instituto de Investigaciones Agropecuarias (INIA Remehue) by extraction with a mixture of distilled water, methanol, and chloroform (Bligh and Dyer, 1959), and methylation with methanol KOH (Ichihara et al., 1996). The derivative was injected into a gas chromatographer at the following weights: initial muscle samples ( $2 \mathrm{~g})$, final muscle samples (20 g), and pasture samples $(50 \mathrm{~g})$.

A completely randomized model was used, which was submitted to a one-way ANOVA with the Minitab Statistical Package, version 14. Measurement contrasting was carried out by the Tukey multiple comparison method for means $(\mathrm{p} \leq 0.05)$.

\section{RESULTS AND DISCUSSION}

Botanic composition of the successional pasture exhibited high species heterogeneity (Table 1) and was not a typical natural pasture of the dryland area (Avendaño et al., 2005; Muñoz et al., 2005) due to its high legume content in which red clover predominated by mid-spring and hualputra (Medicago polimorpha L.) by late spring. This needs to be explained because successional pasture (post cultivation) corresponds to a type of spontaneous pasture that is unpredictable with a large bank of legume seeds from planting in previous years. This explains its high content of red clover (in November), which does not correspond to a typical natural pasture of the dryland. Hualputra is a species that has been naturalized and is found in many soils and depends on soil moisture and the effect of rain.

When analyzing the chemical composition of pasture treatments (Table 2), red clover/Wimmera ryegrass pasture showed the highest $\mathrm{CP}(\mathrm{p} \leq 0.05)$ mean content and a trend towards a lower dry matter (DM) and fiber content as compared to successional and subterranean clover pastures.

Pasture fatty acid composition (Table 3) was similar to that reported for forages in the literature (Demirel et 
Table 1. Botanic composition of pastures during spring expressed as dry matter percentage.

\begin{tabular}{|c|c|c|c|c|c|c|c|c|c|}
\hline \multirow{2}{*}{$\begin{array}{l}\text { Species } \\
(\% \mathrm{DM})\end{array}$} & \multicolumn{3}{|c|}{ Successional pasture } & \multicolumn{3}{|c|}{ Subterranean clover } & \multicolumn{3}{|c|}{ Red clover } \\
\hline & October $^{1}$ & November & December & October & November & December & October & November & December \\
\hline Agrostis tenuis Sibth. & 52.7 & 0.0 & 0.0 & 0.0 & 0.0 & 0.0 & 0.0 & 0.0 & 0.0 \\
\hline Medicago polymorpha $\mathrm{L}$. & 8.3 & 0.8 & 41.9 & 0.0 & 0.0 & 0.0 & 0.0 & 0.0 & 0.0 \\
\hline Cortaderia selloana ${ }^{2}$ & 10.5 & 14.3 & 22.7 & 0.0 & 2.1 & 0.0 & 0.0 & 0.0 & 1.2 \\
\hline Trifolium subterraneum L. & 1.3 & 0.0 & 0.0 & 87.1 & 74.5 & 28.0 & 0.0 & 9.1 & 0.0 \\
\hline Trifolium repens $\mathrm{L}$. & 15.2 & 4.7 & 0.0 & 0.0 & 0.0 & 0.0 & 0.0 & 0.0 & 0.0 \\
\hline Trifolium pratense $\mathrm{L}$. & 1.9 & 54.6 & 1.6 & 0.0 & 0.0 & 0.0 & 81.7 & 50.7 & 50.5 \\
\hline Lolium rigidum Gaudin & 9.5 & 0.0 & 17.9 & 12.9 & 23.5 & 64.5 & 18.3 & 40.3 & 19.6 \\
\hline Bromus hordeaceus L. & 0.6 & 23.7 & 0.0 & 0.0 & 0.0 & 0.0 & 0.0 & 0.0 & 20.5 \\
\hline Others & 0.1 & 1.9 & 16.0 & 0.0 & 0.0 & 7.5 & 0.0 & 0.0 & 8.2 \\
\hline
\end{tabular}

${ }^{1}$ October (10 October 2009); November (11 November 2009); December (15 December 2009).

${ }^{2}$ Cortaderia selloana (Schult. \& Schult. f.) Asch. \& Graebn

al., 2006; Aurousseau et al., 2007). The successional and red clover/Wimmera ryegrass pastures exhibited the highest PUFA numerical values, mainly owing to their high ALNA contents $(\mathrm{p} \leq 0.05)$. This could be explained by the high percentage of red clover found when the successional pasture botanical composition was analyzed. In the subterranean clover/Wimmera ryegrass pasture, higher SFA percentages $(p>0.05)$ would be related to the higher numerical content of mirystic and estearic acids. Red clover/Wimmera ryegrass pasture exhibited the lowest omega6/omega3 rate $(\mathrm{p} \leq 0.05)$ as given by its higher ALNA percentages. Lee et al. (2003) reported that both white and red clover have a higher PUFA content

Table 2. Chemical analysis of pastures grazed before the trial (Initial pasture) and for each treatment during the trial.

\begin{tabular}{lccccc}
\hline & $\begin{array}{c}\text { Initial } \\
\text { pasture }\end{array}$ & $\begin{array}{c}\text { Successional } \\
\text { pasture }\end{array}$ & $\begin{array}{c}\text { Subterranean } \\
\text { clover }\end{array}$ & $\begin{array}{c}\text { Red } \\
\text { clover }\end{array}$ & $\begin{array}{c}\text { p- } \\
\text { value }\end{array}$ \\
\hline $\mathrm{DM}, \%$ & 21.7 & $25.8 \pm 4.49$ & $27.3 \pm 20.07$ & $20.7 \pm 7.70$ & $\mathrm{~ns}$ \\
$\mathrm{TA}, \%$ & 13.2 & $10.0 \pm 2.79$ & $9.5 \pm 0.72$ & $13.6 \pm 4.65$ & $\mathrm{~ns}$ \\
$\mathrm{CP}, \%$ & 17.3 & $14.1 \pm 4.04 \mathrm{~b}$ & $13.6 \pm 2.70 \mathrm{~b}$ & $22.3 \pm 4.58 \mathrm{a}$ & 0.056 \\
$\mathrm{ME}, \mathrm{Mcal} \mathrm{kg}^{-1}$ & 2.7 & $2.50 \pm 0.32$ & $2.51 \pm 0.36$ & $2.62 \pm 0.16$ & $\mathrm{~ns}$ \\
$\mathrm{NDF}, \%$ & 40.7 & $44.9 \pm 5.71$ & $40.2 \pm 9.36$ & $33.5 \pm 3.73$ & $\mathrm{~ns}$ \\
$\mathrm{ADF}, \%$ & 26.7 & $32.0 \pm 6.51$ & $32.8 \pm 8.29$ & $27.1 \pm 1.86$ & $\mathrm{~ns}$ \\
\hline
\end{tabular}

$\mathrm{n}=3$. ns: non significant; DM: dry matter; TA: total ashes; CP: crude protein; ME: metabolizable energy; NDF: neutral detergent fiber; ADF: acid detergent fiber.

Table 3. Fatty acid composition of pastures before the trial (Initial pasture) and for each treatment during the trial (summary table).

\begin{tabular}{|c|c|c|c|c|c|}
\hline $\begin{array}{l}\text { Fatty acids } \\
(\%)\end{array}$ & $\begin{array}{c}\text { Initial } \\
\text { pasture }\end{array}$ & $\begin{array}{l}\text { Successional } \\
\text { pasture }\end{array}$ & $\begin{array}{l}\text { Subterranean } \\
\text { clover }\end{array}$ & $\begin{array}{c}\text { Red } \\
\text { clover }\end{array}$ & $\begin{array}{c}\mathrm{p}- \\
\text { value }\end{array}$ \\
\hline $\begin{array}{l}\text { C14:0 } \\
\text { (myristic acid) }\end{array}$ & 6.40 & $6.15 \pm 3.22$ & $12.03 \pm 12.38$ & $3.83 \pm 2.53$ & ns \\
\hline $\begin{array}{l}\text { C16:0 } \\
\text { (palmitic acid) }\end{array}$ & 18.40 & $19.83 \pm 5.05$ & $19.78 \pm 3.00$ & $19.13 \pm 2.23$ & ns \\
\hline $\begin{array}{l}\text { C18:0 } \\
\text { (estearic acid) }\end{array}$ & 2.80 & $3.67 \pm 1.36$ & $5.10 \pm 2.11$ & $4.60 \pm 1.73$ & ns \\
\hline $\begin{array}{l}\text { C18:1N9C } \\
\text { (oleic acid) }\end{array}$ & 1.25 & $3.00 \pm 1.16$ & $5.45 \pm 3.57$ & $5.40 \pm 6.26$ & ns \\
\hline $\begin{array}{l}\text { C18:2N6C } \\
\text { (linoleic acid) }\end{array}$ & 8.55 & $10.50 \pm 3.37$ & $13.58 \pm 6.82$ & $11.30 \pm 5.93$ & ns \\
\hline $\begin{array}{l}\mathrm{C} 18: 3 \mathrm{~N} 3 \\
(\alpha \text { linolenic acic }\end{array}$ & id) 24.55 & $32.32 \pm 10.34 b$ & $23.75 \pm 11.47 b$ & $42.80 \pm 12.53 a$ & 0.037 \\
\hline SFA & 36.15 & $32.98 \pm 4.89$ & $40.60 \pm 15.77$ & $29.43 \pm 3.81$ & ns \\
\hline PUFA & 53.30 & $60.82 \pm 9.01$ & $52.22 \pm 14.82$ & $60.08 \pm 11.97$ & ns \\
\hline MUFA & 10.55 & $5.47 \pm 5.15$ & $7.10 \pm 5.56$ & $10.42 \pm 8.79$ & ns \\
\hline$\omega 6 / \omega 3$ & 1.17 & $0.71 \pm 0.50 \mathrm{~b}$ & $1.39 \pm 0.71 \mathrm{a}$ & $0.37 \pm 0.34 \mathrm{c}$ & 0.013 \\
\hline
\end{tabular}

$\mathrm{n}=3$. ns: non significant; SFA: saturated fatty acids; PUFA: polyunsaturated fatty acids MUFA: monounsaturated fatty acids; $\omega 6 / \omega 3$ : omega6/omega3 rate. than a natural pasture mainly with Lolium perenne. This result does not coincide with the findings of this study because of the high legume content found in the natural pasture that resulted in a lower omega6/omega3 rate than in the subterranean clover/Wimmera ryegrass pasture.

Regarding lamb productive characteristics (Table 4), the means for daily weight gain, final weight, weight before slaughter, and hot carcass weight were all higher in lambs fed on the red clover/Wimmera ryegrass pasture $(\mathrm{p} \leq 0.05)$ as compared to the other treatments. Gallardo et al. (2008), working with Suffolk Down lambs in the same geographical area, reported weight gains of $399 \mathrm{~g} \mathrm{~d}^{-1}$ for lambs and $391 \mathrm{~g} \mathrm{~d}^{-1}$ for ewes consuming subterranean clover pastures, values somewhat higher than those reported for legume pastures in this trial $\left(259 \mathrm{~g} \mathrm{~d}^{-1}\right.$ for subterranean and $296 \mathrm{~g} \mathrm{~d}^{-1}$ for red clover), which could be explained by the shorter duration of the cited trial $(15 \mathrm{~d})$ and by the lower lamb age (Avendaño et al., 1994).

Chemical analysis of the L. dorsi muscle of lambs fed on different pastures (Table 5) showed significant differences only for $\mathrm{CP}$ and ether extract (EE) $(\mathrm{p} \leq 0.01)$. The higher mean protein values found in the red clover/Wimmera ryegrass pasture were not reflected in higher mean protein

Table 4. Productive characteristics in lambs fed on three pasture types.

\begin{tabular}{|c|c|c|c|c|}
\hline & $\begin{array}{l}\text { Successional } \\
\text { pasture }^{1}\end{array}$ & $\begin{array}{c}\text { Subterranean } \\
\text { clover }^{1}\end{array}$ & $\begin{array}{c}\text { Red } \\
\text { clover }^{1}\end{array}$ & $\begin{array}{c}\mathrm{p}- \\
\text { value }\end{array}$ \\
\hline Initial weight, $\mathrm{kg}$ & $28.4 \pm 3.78$ & $29.8 \pm 3.82$ & $30.1 \pm 2.56$ & ns \\
\hline Final weight, $\mathrm{kg}$ & $43.0 \pm 4.79 b$ & $46.9 \pm 5.56 \mathrm{ab}$ & $49.6 \pm 1.97 \mathrm{a}$ & 0.036 \\
\hline DWG, $\mathrm{g} \mathrm{d}^{-1}$ & $0.221 \pm 0.04 \mathrm{c}$ & $0.259 \pm 0.03 b$ & $0.296 \pm 0.05 a$ & 0.006 \\
\hline Weight before slaughter, $\mathrm{kg}$ & $41.2 \pm 4.01 \mathrm{~b}$ & $41.9 \pm 4.12 b$ & $46.0 \pm 2.99 \mathrm{a}$ & 0.055 \\
\hline Hot carcass weight, $\mathrm{kg}$ & $21.4 \pm 2.24 b$ & $22.0 \pm 2.27 b$ & $24.5 \pm 1.19 \mathrm{a}$ & 0.021 \\
\hline Hot carcass dressing, $\%^{2}$ & $0.52 \pm 0.02$ & $0.52 \pm 0.02$ & $0.53 \pm 0.02$ & ns \\
\hline
\end{tabular}

Table 5. Chemical analysis of Longissimus dorsi muscle in lambs fed on three types of pastures.

\begin{tabular}{lcccc}
\hline & $\begin{array}{c}\text { Successional } \\
\text { pasture }^{1}\end{array}$ & $\begin{array}{c}\text { Subterranean } \\
\text { clover }^{1}\end{array}$ & $\begin{array}{c}\text { Red } \\
\text { clover }^{1}\end{array}$ & $\begin{array}{c}\text { p- } \\
\text { value }\end{array}$ \\
\hline $\mathrm{DM}, \%$ & $23.8 \pm 0.00$ & $24.5 \pm 0.00$ & $24.0 \pm 0.00$ & $\mathrm{~ns}$ \\
$\mathrm{TA}, \%$ & $1.1 \pm 0.01$ & $1.1 \pm 0.01$ & $1.1 \pm 0.02$ & $\mathrm{~ns}$ \\
$\mathrm{CP}, \%$ & $19.0 \pm 0.06 \mathrm{c}$ & $20.2 \pm 0.06 \mathrm{a}$ & $19.6 \pm 0.13 \mathrm{~b}$ & 0.000 \\
$\mathrm{EE}, \%$ & $2.8 \pm 0.02 \mathrm{a}$ & $2.3 \pm 0.00 \mathrm{c}$ & $2.4 \pm 0.05 \mathrm{~b}$ & 0.000 \\
$\mathrm{CF}, \%$ & $0.1 \pm 0.00$ & $0.1 \pm 0.00$ & $0.1 \pm 0.01$ & $\mathrm{~ns}$ \\
\hline
\end{tabular}

In = 7; DM: dry matter; TA: total ashes; CP: crude protein; EE: ether extract; CF: crude fiber; ns: non significant. 
levels in the meat of lambs fed on this forage. Although final weight and weight gains were higher in lambs fed on red clover/Wimmera ryegrass, these animals showed intermediate values of $\mathrm{EE}$ in their meat, which were not related to higher carcass fat contents.

Fatty acid composition of $L$. dorsi muscle in the lambs from the different treatments (Table 6) was within the values reported by the literature for grazing sheep (Enser et al., 1996; Demirel et al., 2006). Notwithstanding that grazing systems increase ALNA concentrations in meat (Givens et al., 2006), ALNA quantities in the forages turned out to be much higher than those found in meat (except in the case of $18: 2 n 6$ ), which can be due to a higher ruminal biohydrogenation suffered by ALNA ( 85 to $100 \%$ ) as compared to the biohydrogenation of 18:2n-6 (70 to 95\%) (Doreau and Ferlay, 1994). Values reported for PUFA in this trial are higher than those reported by other authors (Aurousseau et al., 2007; Cañeque et al., 2007); this is probably due to the higher $18: 2 \mathrm{n}-6$ and 18:3n-3 levels observed in the present study (Enser et al., 1998; Fisher et al., 2000), which could be explained by the high clover content in all the pastures.

When comparing the initial muscle samples (obtained by biopsy) with the samples obtained at the end of the trial, a decrease in the percentage of SFA $(\mathrm{p} \leq 0.05)$ and an increase in PUFA $(\mathrm{p} \leq 0.05)$ were observed. This effect could be explained by the likely decrease in the lambs' milk consumption throughout the trial and the corresponding increase in forage consumption. Final meat samples also exhibited a higher $\omega 6 / \omega 3$ rate $(\mathrm{p} \leq 0.05)$ given their greater numerical contents of $\mathrm{C} 18: 2 \mathrm{n} 6$ and C18:3n3.

In general, no significant differences among treatments were found when comparing muscle samples obtained at the end of the trial (except in certain individual fatty acids) with regards to SFA and PUFA contents. The $\omega 6 /$ $\omega 3$ rate was $<2.2$ in all treatments, thus making the lamb meat highly recommendable for consumption $(<4)$ (Scollan et al., 2006). There was a trend for the meat of lambs fed on red clover/Wimmera ryegrass pasture $(\mathrm{p}>$ 0.06 ) to contain higher numerical percentages of MUFA as compared to the other two pastures, which could be explained by the higher oleic acid content $(18: 1 \mathrm{n} 9)$ of this pasture. Lee et al. (2009b) fed dairy cull cows with grass silage and red clover silage, reporting significantly higher values of oleic acid in clover although this was not reflected in the meat. Contrary to what was expected, lamb meat from the successional pasture was not different from meat from pastures based on clover (subterranean or red). This can be due to the high content of red clover (midspring) and hualputra (late spring) found when analyzing the botanic composition of the successional pasture, thus making this pasture similar to the other two in terms of legume content.

It is known that the effect of grazing on meat fatty acid composition will depend on the forage species consumed (Lee et al., 2009a). The better results with red clover to increase muscle fatty acid composition reported so far would be linked to a decrease in ruminal biohydrogenation. This has been explained through the protective effects of the polyphenol oxidasa (PPO) enzyme (Lee et al., 2004) that allows a higher proportion of ALNA to escape from ruminal biohydrogenation and is reflected in meat composition. However, that effect was not observed in this trial. Although red clover/Wimmera ryegrass pasture lambs exhibited the highest percentage of ALNA in their meat, no significant differences were found in this trial when compared with the meat from the lambs grazing on successional or subterranean clover/ Wimmera ryegrass pasture. Another important factor to be considered is the use of forage mixtures (as in this study) instead of monocultures. Lourenco et al. (2008) reported that lambs fed on a mixture of legumes and other forages would show more PUFA at muscle level than animals fed only on pastures (result observed in this trial given the high legume content in the successional pasture). For the same reason, there were no significant differences among treatments regarding CLA content in the meat.

\section{CONCLUSIONS}

The botanic composition of pastures grazed by the lambs varied as spring advanced and the successional pasture

Table 6. Main fatty acid composition of Longissimus dorsi muscle in lambs before the trial (Initial) and after grazing on three types of pastures.

\begin{tabular}{|c|c|c|c|c|c|}
\hline Fatty acids $(\%)$ & $\begin{array}{l}\text { Initial } \\
(\mathrm{n}=3)\end{array}$ & $\begin{array}{l}\text { Successional pasture } \\
(\mathrm{n}=7)\end{array}$ & $\begin{array}{l}\text { Subterranean clover } \\
(\mathrm{n}=7)\end{array}$ & $\begin{array}{l}\text { Red clover } \\
\quad(n=7)\end{array}$ & p-value \\
\hline C14:0 (myristic acid) & $9.22 \pm 0.84 \mathrm{a}$ & $1.37 \pm 0.98 b$ & $1.25 \pm 1.10 \mathrm{~b}$ & $1.76 \pm 1.46 \mathrm{~b}$ & ns \\
\hline C16:0 (palmitic acid) & $29.25 \pm 3.45 \mathrm{a}$ & $18.33 \pm 2.10 \mathrm{c}$ & $18.57 \pm 2.62 \mathrm{c}$ & $21.17 \pm 3.77 b$ & 0.024 \\
\hline C18:0 (estearic acid) & $19.00 \pm 4.20 \mathrm{a}$ & $15.08 \pm 1.00 \mathrm{~b}$ & $17.72 \pm 2.24 \mathrm{a}$ & $15.28 \pm 4.64 b$ & 0.048 \\
\hline C18:1N9C (oleic acid) & $31.14 \pm 10.68 \mathrm{a}$ & $22.81 \pm 2.98 b$ & $23.72 \pm 4.85 b$ & $27.04 \pm 4.19 \mathrm{a}$ & 0.023 \\
\hline CLA (conjugated linoleic acid) & nd & $0.24 \pm 0.63$ & $0.17 \pm 0.23$ & $0.22 \pm 0.21$ & ns \\
\hline C18:2N6C (linoleic acid) & $2.81 \pm 0.94 b$ & $16.21 \pm 3.08 \mathrm{a}$ & $15.91 \pm 4.98 \mathrm{a}$ & $13.98 \pm 5.34 \mathrm{a}$ & ns \\
\hline C18:3N3( $\alpha$ linolenic acid) & $1.99 \pm 0.49 b$ & $4.92 \pm 0.76 \mathrm{a}$ & $5.33 \pm 1.24 \mathrm{a}$ & $4.31 \pm 1.71 \mathrm{a}$ & ns \\
\hline SFA & $60.33 \pm 8.70 \mathrm{a}$ & $36.20 \pm 3.53 b$ & $38.98 \pm 4.83 b$ & $39.05 \pm 6.40 \mathrm{~b}$ & ns \\
\hline PUFA & $5.81 \pm 2.11 b$ & $27.20 \pm 4.14 \mathrm{a}$ & $25.97 \pm 70.24 a$ & $23.03 \pm 7.83 \mathrm{a}$ & ns \\
\hline MUFA & $33.91 \pm 10.85$ & $28.44 \pm 2.91$ & $29.25 \pm 4.72$ & $31.86 \pm 3.75$ & ns \\
\hline$\omega 6 / \omega 3$ & $0.94 \pm 0.08 b$ & $1.81 \pm 0.20 \mathrm{a}$ & $2.05 \pm 0.57 \mathrm{a}$ & $1.87 \pm 0.43 \mathrm{a}$ & ns \\
\hline
\end{tabular}

nd: not determined; ns: non significant among the three treatments, but significant when compared with the initial samples; SFA: saturated fatty acids; PUFA: polyunsaturated fatty acids; MUFA: monounsaturated fatty acids; $\omega 6 / \omega 3$ : omega6/omega3 rate. 
contained high levels of legumes, which resembled the contents of red clover and subterranean clover in the other grazing systems. Lamb productive performance in terms of weight gains and final live weight was higher in the red clover/Wimmera ryegrass pasture $(\mathrm{p} \leq 0.05)$ without producing an increase in chemical fat content of $L$. dorsi.

Muscle fatty acid composition did not differ significantly among treatments $(\mathrm{p}>0.05)$ with regards to SFA and PUFA content, and the $\omega 6 / \omega 3$ rate, the latter being very favorable for human consumption $(<4)$ in all treatments. The fact that the meat from lambs grazing successional pasture was not different from meat obtained from lambs grazing clover pastures can be due to the high legume content of this particular successional pasture, making it impossible to extrapolate results to other natural pastures of the dryland area. In summary, the use of subterranean clover would provide similar meat quality when compared to results obtained from forage based on red clover.

\section{ACKNOWLEDGEMENTS}

We thank Druso Pérez, Miguel Ruiz Albarrán, Rodrigo Morales, and especially Ana Paula Aguiar for their collaboration in this study.

\section{Composición de ácidos grasos del músculo Longissimus dorsi de corderos Suffolk Down} alimentados con diferentes forrajes. La producción ovina en el secano está basada en la pradera natural. El objetivo de este estudio fue evaluar el efecto de praderas de leguminosas de secano sobre la composición de ácidos grasos de la carne de cordero. El estudio incluyó 21 corderos machos Suffolk Down, de alrededor de 2 meses de edad, los que fueron asignados aleatoriamente en tres praderas: pradera sucesional, trébol subterráneo/ ballica Wimmera (Trifolium subterraneum L./Lolium rigidum Gaudin) o trébol rosado/ballica Wimmera $(T$. pratense L./L. rigidum), por $66 \mathrm{~d}$, siendo posteriormente sacrificados. El perfil de ácidos grasos, medido en el músculo Longissimus dorsi no mostró diferencias significativas en contenido de ácidos grasos saturados (SFA), poliinsaturados (PUFA), y razón omega 6/omega $3(\omega 6 / \omega 3)$. Hubo una tendencia $(\mathrm{p}>0,06)$ hacia un mayor contenido de ácidos grasos monoinsaturados (MUFA) en la carne de corderos alimentados con trébol rosado, comparado con los otros tipos de praderas. Aunque no hubo diferencias significativas entre tratamientos, los resultados obtenidos con la pradera sucesional no pueden ser extrapolados a pasturas naturales en el secano, debido a sus altos contenidos de leguminosas. Se concluye que el uso de trébol subterráneo proveería una similar calidad de carne, al comparar con forrajes basados en trébol rosado.

Palabras clave: carne de cordero, grasa muscular, praderas de leguminosas.

\section{LITERATURE CITED}

Andersson, A., C. Nälsén, S. Tengblad, and B. Vessby. 2002. Fatty acid of skeletal muscle reflects dietary fat composition in humans. American Journal of Clinical Nutrition 76:1222-1229.

AOAC. 1996. Official methods of analysis. $16^{\text {th }}$ ed. Association of official analytical chemists (AOAC), Arlington, Virginia, USA.

Aurousseau, B., D. Bauchart, X. Faure, A.L. Galot, S. Prache, D. Micol, and A. Priolo. 2007. Indoor fattening of lambs raised on pasture: (1) Influence of stall finishing duration on lipid classes and fatty acids in the longissimus thoracis muscle. Meat Science 76:241.252.

Avendaño, J., C. Ovalle, y A.T. Aravena. 1994. Sistema extensivo de producción ovina en pradera anual del secano mediterráneo subhúmedo. Agricultura Técnica 54:293-301.

Avendaño, J., C. Ovalle, A. Del Pozo, F. Fernández, y C. Porqueddu. 2005. Mezclas de trébol subterráneo con otras leguminosas anuales para suelos graníticos del secano mediterráneo subhúmedo de Chile. Agricultura Técnica 65:165-176.

Bateman, J.V. 1970. Nutrición animal. Manual de métodos analíticos. 468 p. México D.F.

Bligh, E.G., and W.J. Dyer. 1959. A rapid method of total lipid extraction and purification. Canadian Journal of Physiology and Pharmacology 37:911-917.

Cañeque, V., J. De la Fuente, M.T. Díaz, y I. Alvarez. 2007. Composición en ácidos grasos y vitamina E de la carne de corderos alimentados con niveles diferentes de concentrado. Instituto Nacional de Investigación Agropecuaria INIA Uruguay. Serie Técnica 168:97-102.

Demirel, G., H. Ozpinar, B. Nazli, and O. Keser. 2006. Fatty acids of lamb meat from two breeds fed different forage: concentrate ratio. Meat Science 72:229-235.

Doreau, M., and A. Ferlay. 1994. Digestion and utilisation of fatty acids by ruminants. Animal Feed Science and Technology 45:379396.

Enser, M., K. Hallett, B. Hewitt, G.A.J. Fursey, and J.D. Wood. 1996. Fatty acid content and composition of English beef, lamb and pork at retail. Meat Science 42:443-456.

Enser, M., K. Hallett, B. Hewitt, G.A.J. Fursey, and J.D. Wood 1998. Fatty acid content and composition of UK beef and lamb muscle in relation to production system and implications for human nutrition. Meat Science 49:329-341.

Fisher, A.V., M. Enser, R.I. Richardson, J.D. Wood, G.R. Nute, E. Kurt, et al. 2000. Fatty acid composition and eating quality of lamb types derived from four diverse breed $\times$ production systems. Meat Science 55:141-147.

Gallardo, M.A. 2004. Modificación de la composición de ácidos grasos en pollos broiler a través de la alimentación con aceite de canola. Tesis de Magister. Pontificia Universidad Católica de Chile, Facultad de Agronomía, Santiago, Chile.

Gallardo, M.A., R. Allende, C. Ovalle, S. Rojas, I. Briones, y D. Troncoso. 2008. Utilización de praderas mediterráneas: Estudio descriptivo en secano interior de la VII Región para engorda de corderos. XXXIII Reunión Anual Sociedad Chilena de Producción Animal (SOCHIPA), Valdivia. Libro de resúmenes: 195-196. SOCHIPA, Santiago, Chile.

Givens, D.I., K.E. Liem, and R.A. Gibbs. 2006. The role of meat as a source of $n-3$ polyunsaturated fatty acids in the human diet. Meat Science 74:209-218.

Goering, H.K., and P.J. Van Soest. 1970. Forage fiber analysis. Agriculture Handbook $\mathrm{N}^{\circ}$ 379. p. 19. Agriculture Research Service-USDA, Washington D.C., USA.

Ichihara, K., A. Shibahara, K. Yamamoto, and T. Nakayama. 1996. An improved method for rapid analysis of the fatty acids of glycerolipids. Lipids 31:535-539.

Lee, M.R., P.R. Evans, G.R. Nute, R.I. Richardson, and N.D. Scollan. 2009 b. A comparison between red clover silage and grass silage feeding on fatty acid composition, meat stability and sensory quality of the M. Longissimus muscle of dairy cull cows. Meat Science 81:738-744. 
Lee, M.R., L. Harris, R. Dewhurst, R. Merry, and N.D. Scollan. 2003. The effect of clover silages on long chain fatty acid rumen transformations and digestion in beef steers. Animal Science76:491-501.

Lee, M., J. Tweed, F. Minchin, and A. Winters. 2009a. Red clover polyphenol oxidase: activation, activity and efficacy under grazing. Animal Feed Science and Technology 149:250-264.

Lee, M.R.,A. Winters, N.D. Scollan, R.J. Dewhurst, M.K. Theodorou, and F.R. Minchin. 2004. Plant-mediated lipolysis and proteolysis in red clover with different polyphenol oxidase activities. Journal of the Science of Food and Agriculture 84:1639-1645.

Lourenco, M., G. Van Ranst, B. Vlaeminck, S. De Smet, and V. Fievez. 2008. Influence of different dietary forages on the fatty acid composition of rumen digesta as well as ruminant meat and milk. Animal Feed Science and Technology 145:418-437.

Muñoz, M., A. Garrido, y D. Troncoso. 2005. Caracterización de la pradera natural en el secano interior mediterráneo de la Región del Maule. 56 Congreso Agronómico, Chillán. Simiente 75(3-4):44.
Scollan, N.D., P. Costa, K.G. Hallett, G.R. Nute, J.D. Wood, and R.I. Richardson. 2006. The fatty acid composition of muscle fat and relationships to meat quality in Charolais steers: Influence of level of red clover in the diet. Proceedings of the British Society of Animal Science, April. p. 23.

Simopoulos, A.P. 2000. Symposium: Role of poultry products in enriching the human diet with n-3 PUFA. Human requirement for n-3 poliunsaturated fatty acids. Poultry Science 79:961-970.

Tilley, J., and R. Terry. 1963. A two stages technique for the in vitro digestion of forages crops. Journal of British Grassland Society 18:104-111.

Van Soest, P.J., J. Robertson, and B. Lewis. 1991. Methods for dietary fiber, neutral detergent fiber, and nonstarch polysaccharides in relation to animal nutrition. Journal of Dairy Science 74:35833595 .

Wood, J., M. Enser, A. Fisher, G. Nute, P. Sheard, R. Richardson, et al. 2008. Fat deposition, fatty acid composition and meat quality: a Review. Meat Science 78:343-358. 